\title{
Laser-induced ocular injury: a narrative review
}

Eva WN Wong, MBChB, MRCSEd(Ophth); Anthony CH Lai, MBChB, MRCSEd(Ophth); Robert F Lam, MPH, FHKAM(Ophthalmology); Frank HP Lai, FRCSEd(Ophth), FHKAM(Ophthalmology)

Department of Ophthalmology, Caritas Medical Centre, Hong Kong

Correspondence and reprint requests:

Dr Frank HP Lai, Department of Ophthalmology, Caritas Medical Centre, 111 Wing Hong Street, Sham Shui Po, Hong Kong.

Email:franklhp@gmail.com

\section{Abstract}

There is an increasing trend of reported laser-induced ocular injury. We aimed to review the literature on the basic principles of laser, clinical management and safety precaution of laser-induced ocular injury. A literature search on the PubMed database was conducted to include articles dated up to April 2020. One example case of laser-induced ocular injury is provided. Clinical presentation of laser-induced ocular injury is variable. The clinical features can be transient and subtle. Appropriate investigations are useful to establish a diagnosis and to evaluate the severity of the injury. Laser-induced ocular injury most commonly involves the macula, which can be complicated by intraocular haemorrhage, macular hole, epiretinal membrane, and choroidal neovascularization. There are currently no evidence-based or well-recognized treatments for laser-induced retinopathy. Surgical intervention might be considered if there is significant intraocular hemorrhage or macular hole. Laser-induced ocular injury may cause permanent visual sequelae and functional disability. Diagnosis of an eye injury should be supported by objective clinical findings and/ or appropriate investigations. As medical and surgical treatment options are currently limited, the key to combat laser ocular injuries lies in prevention and awareness of the general public should be reinforced.

Key words: Eye injuries; Lasers; Safety

\section{Introduction}

Laser has been widely used for occupational, military, medical, and cosmetic purposes. ${ }^{1}$ There is an increasing trend of laser-related ocular injuries secondary to high-powered handheld laser devices. ${ }^{2}$ Lack of awareness regarding the sight-threatening hazards of these devices may lead to inadvertent or deliberate laser use. ${ }^{3}$ Laser-induced ocular injury in children is a major public health issue. ${ }^{4}$ Aircraft risks attributable to laser strikes have been reported. ${ }^{5}$ Public awareness regarding the hazardous effect of laser should be reinforced. ${ }^{6}$ The aim of this study is to review the literature on the investigation and management of laser-induced ocular injury, as well as safety precautions that can be taken.

\section{Example case}

In January 2020, a 14-year-old boy presented to an eye clinic 4 days after having a sudden drop of left eye vision while playing with a laser pointer at home. At presentation, visual acuity of the right eye and left eye was 20/25 and 20/60, respectively. Fundal examination of his left eye revealed cystoid changes at the fovea, but there was no anterior segment injury or retinal or vitreous hemorrhage. The involved laser pointer was not available for verification of its power and specification. Optical coherence tomography (OCT) of the left eye macula showed subfoveal cystoid change with disruption of inner segment-outer segment junction (Figure 1a). The retinal pigment epithelium (RPE) layer was intact. The patient was treated with topical $1 \%$ prednisolone acetate four times per day and $0.1 \%$ nepafenac three times per day for one week. The visual acuity of his left eye gradually improved to 20/30 at 3 weeks. The cystoid changes at the macula was subsequently resolved. OCT of the left eye macula showed resolution of cystoid changes, re-establishment of inner segment-outer segment junction continuity and foveal depression (Figure 1b). There was no discernible anatomical 


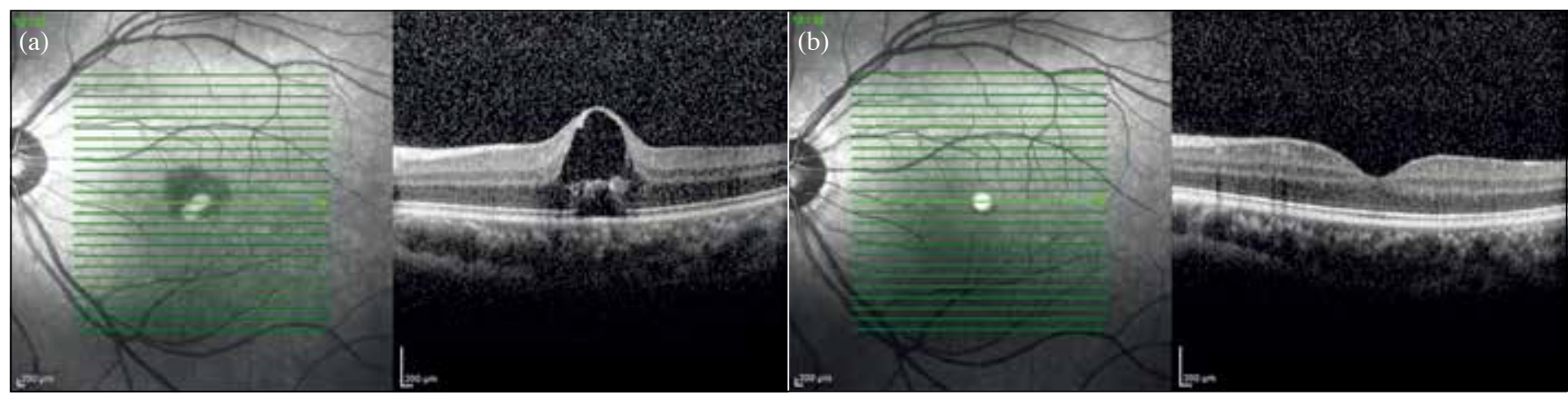

Figure 1. Optical coherence tomography of the left eye fovea (a) at 4 days after the laser-induced injury showing cystoid change at fovea with disruption of inner segment-outer segment junction, an intact retinal pigment epithelium, and a central macular thickness of $518 \mu \mathrm{m}$. (b) at 3 weeks after injury showing resolution of cystoid changes, re-establishment of inner segment-outer segment junction continuity and foveal depression.

\begin{tabular}{|c|c|c|c|c|}
\hline $\begin{array}{l}\text { Class of } \\
\text { laser }\end{array}$ & $\begin{array}{l}\text { Output } \\
\text { power, } \mathrm{mW}\end{array}$ & Risk & Precaution & Example \\
\hline 1/1M & $<0.4$ & $\begin{array}{l}\text { Considered not hazardous during normal operation } \\
\text { unless viewed through specific optical instrument }\end{array}$ & $\begin{array}{l}\text { Exempt from control measures or surveillance other } \\
\text { than to prevent potentially hazardous optically aided } \\
\text { viewing }\end{array}$ & $\begin{array}{l}\text { Laser printers, } C D \text { and } \\
\text { DVD players }\end{array}$ \\
\hline $2 / 2 \mathrm{M}$ & $<1$ & $\begin{array}{l}\text { Low risk: safe for brief momentary exposure; may } \\
\text { be harmful with prolonged direct viewing or viewed } \\
\text { with optical aids }\end{array}$ & $\begin{array}{l}\text { Eye protection afforded by the aversion response; } \\
\text { prevent viewing through hazardous optical } \\
\text { instruments }\end{array}$ & Barcode scanners \\
\hline $3 \mathbf{R}$ & $<5$ & $\begin{array}{l}\text { Moderate risk: potentially hazardous under direct } \\
\text { and specular reflection viewing if eye is focused and } \\
\text { stable }\end{array}$ & $\begin{array}{l}\text { Avoid direct beam viewing; wear laser protective } \\
\text { eyewear; prevent unintentional specular reflections }\end{array}$ & $\begin{array}{l}\text { Laser pointers for } \\
\text { presentation and } \\
\text { recreational use }\end{array}$ \\
\hline 3B & $<500$ & $\begin{array}{l}\text { Moderate risk: potentially hazardous under direct } \\
\text { and specular reflection viewing }\end{array}$ & $\begin{array}{l}\text { As class 3R; designated laser controlled area and } \\
\text { laser safety officer required under Hospital Authority } \\
\text { regulations }\end{array}$ & \multirow[t]{2}{*}{$\begin{array}{l}\text { Majority of industrial, } \\
\text { military and medical } \\
\text { lasers }\end{array}$} \\
\hline 4 & $>500$ & $\begin{array}{l}\text { High risk: Hazardous to the eye or skin from } \\
\text { direct beam; diffuse reflection or fire hazard; laser } \\
\text { generated air contaminants; plasma radiation }\end{array}$ & $\begin{array}{l}\text { As class } 3 R \text {; protective clothing required if } \\
\text { maximum permissible exposure for the skin is } \\
\text { exceeded }\end{array}$ & \\
\hline
\end{tabular}

abnormality detected. Although outer retinal damages are common in laser-related injury, intraretinal fluid with cystoid change is an uncommon presentation. ${ }^{7}$

\section{Literature search}

The PubMed, EMBASE, and Web of Science databases were searched for articles published between 1998 and May 2020 using keywords: 'laser' and 'eye injury' and 'ocular injury' or 'laser eye injury' or 'laser ocular injury' or 'laser retinal injury' or laser macular injury' or 'laser induced maculopathy or 'laser induced retinopathy' or 'laser pointer'. Of 4969 articles yielded, 4637 duplicated or irrelevant articles were excluded and 332 articles were included. References in the included articles were reviewed to identify additional relevant studies. Of the 332 articles, those written in languages other than English were excluded, as were statements, editorials, and letters to the editor. Eventually, 157 articles were reviewed. Internationally adopted guidelines and safety manuals regarding laser use were referenced.

\section{Classification and application of laser}

A laser is a monochromatic, coherent, and collimated light beam that is polarized, minimally divergent, and has a single frequency. Lasers are classified by the maximum output power into four classes (Table 1): class 1 is safe under all conditions of normal use, whereas class 4 is hazardous to the eye or skin and may pose a diffuse reflection or fire hazard..$^{89}$ Classes 3 and 4 laser are commonly applied in ophthalmological equipment for the treatment of various ocular conditions such as glaucoma and retinal diseases.

Laser pointers are widely used in educational and business presentations, amateur astronomy, construction work, and entertainment purpose. They are available in various colors on the visible light spectrum, with the most common being green $(532 \mathrm{~nm})$ or red $(650-670 \mathrm{~nm})$ diode laser. ${ }^{10,11}$ Most consumer laser pointers are categorized as class $3 \mathrm{R}$ with output power of $<5 \mathrm{~mW}$, which is relatively safe to human eyes upon accidental viewing due to limitation of exposure 


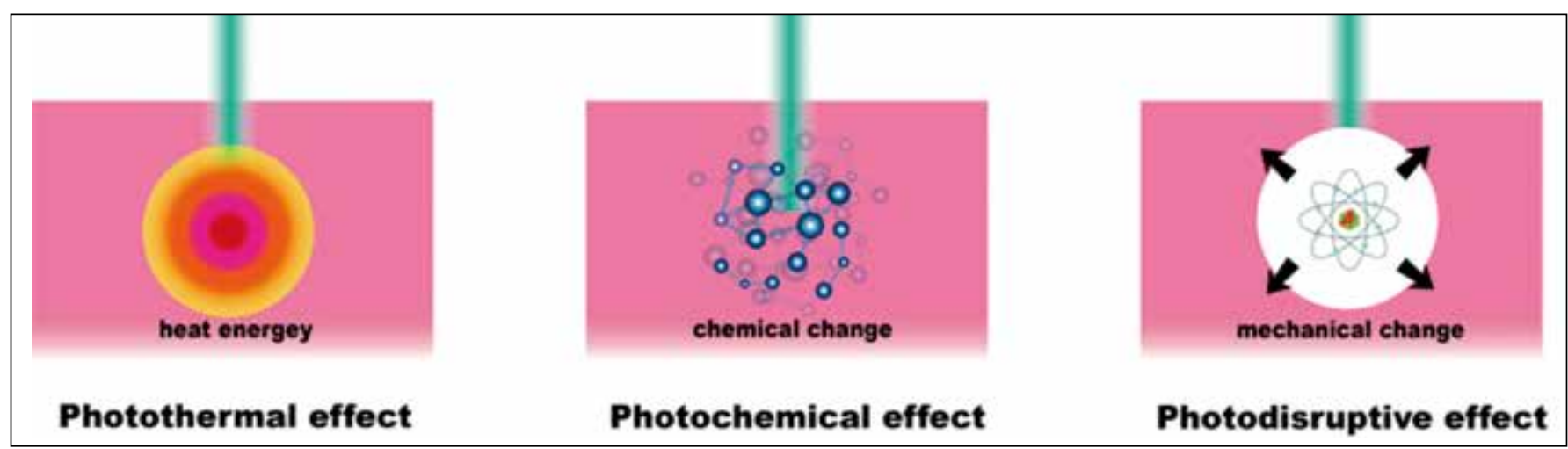

Figure 2. Photothermal effect involves a local temperature rise owing to absorption of laser energy, leading to protein denaturation and tissue damage. Photochemical effect occurs when laser energy induces chemical reactions in the absorbing molecules without significant build-up of heat. Photodisruptive effect happens when rapidly absorbed laser energy causes disintegration of tissue into plasma, eventually leading to mechanical disruption of surrounding tissues.

time by the blink reflex and aversion response. However, mislabeling of output power may impose hidden danger. In a test of 122 commercial laser pointers, $89.7 \%$ of green pointers and $44.4 \%$ of red pointers labeled as class $3 \mathrm{R}$ devices had a power output of $>5 \mathrm{~mW},{ }^{10}$ and $52.4 \%$ of the tested devices exceeded the legal limit by at least a factor of 2 at one or more wavelengths. In Hong Kong, there are no regulations on the usage or purchase of laser pointers. As for sellers, it is an offence to supply or manufacture goods unless it complies with the safety requirements under the Consumer Goods Safety Ordinance. ${ }^{12}$ In many other jurisdictions, the power of laser pointer available to the general public is restricted to $<5 \mathrm{~mW} .^{13}$

\section{Mechanisms of laser-induced eye injury}

Laser-tissue interaction in the eye involves three mechanisms: photothermal, photochemical, and photodisruptive (Figure 2). Photothermal interaction occurs when laser energy is absorbed by a chromophore, such that the rate of heat energy production is greater than the rate of energy dissipation, leading to local temperature rise. ${ }^{1,14,15}$ An increase in temperature causes protein denaturation and coagulation, resulting in cell death followed by tissue necrosis and scarring. ${ }^{15}$ Photochemical interaction occurs when laser energy is delivered at relatively low power and long pulses and induces chemical reactions in the absorbing molecules without significant build-up of heat. ${ }^{1,16}$ Photodisruptive interaction occurs when energy is absorbed rapidly at a pulse duration of picoseconds to nanoseconds. A rapid increase in temperature causes stripping of electrons from atoms and disintegration of tissue into plasma. ${ }^{14}$ In combination with the ensuing vaporization of water molecules, a compressive pressure pulse is generated, mechanically disrupting the surrounding tissues. ${ }^{1,14}$

\section{Effects of laser to ocular tissue}

The tissue involved in laser-induced ocular injury depends on the optical property of ocular structures and the wavelength of the laser. Laser-induced injury to ocular structures other than the retina is uncommon, as they are optically transparent in the visible and near-infrared spectrum. Lasers in these wavelengths are transmitted by the optical media of the eye and focused onto the retina by its refractive components (cornea, aqueous humor, lens, vitreous humor) ${ }^{17}$ The refractive power of the cornea and lens can produce retinal irradiance of up to $10^{5}$ times greater than corneal irradiance. ${ }^{18}$ With the use of binoculars or other magnifying optics, the increase in irradiance may be more than a million fold. ${ }^{1}$ This makes the retina highly susceptible to laser injury. Melanin pigment, which is abundant in the retinal pigment epithelium, absorbs laser energy and leads to a localized temperature elevation or even a plasma formation. ${ }^{18}$ Continuous-wave lasers such as argon laser and lasers from commercial laser pointers can cause retinal injury mainly by photothermal mechanism, whereas Q-switched lasers such as Nd:YAG laser can cause retinal injury by photodisruptive effect. Q-switched laser injury tends to be more dangerous because they can produce very high power concentration at a localized site. ${ }^{1,14}$ In contrast, laser in the ultraviolet spectrum is rapidly absorbed by the cornea, causing corneal injury by the photochemical mechanism. ${ }^{1,19}$ One such example is the excimer laser (with wavelength of $193 \mathrm{~nm}$ ) in keratorefractive surgeries. Laser with longer wavelength, such as the mid-infrared $\mathrm{CO}_{2}$ laser, is readily absorbed by water molecules in any tissue. It does not penetrate deeper than $100 \mu \mathrm{m}$ into the cornea but may result in corneal and scleral injury or injury of the external adnexa by the photothermal mechanism. ${ }^{1,20}$

Clinical presentation of laser-induced ocular injury

Clinical presentations of ocular laser injury vary, depending on the type of laser, duration of exposure, and the method of administration (Table 2) ${ }^{4}$ The retina (the macula in particular) is most susceptible to laser injuries. ${ }^{2,21,22}$ The wide availability of handheld laser devices is associated with an increased incidence of pediatric laser-induced ocular injury, 2,22,23 accounting for $70 \%$ to $80 \%$ of reported cases. ${ }^{4,22}$ Handheld laser devices have been reported to be associated with playing with laser, ${ }^{21}$ accidental injury inflicted by others, ${ }^{21}$ selfinflicted injury, ${ }^{24}$ intentional self-harm, ${ }^{25}$ and assault. ${ }^{26}$ Other mechanisms of injury include occupational, ${ }^{27}$ recreational, ${ }^{28}$ medical, ${ }^{29-36}$ military, ${ }^{37,38}$ and air flight exposure to laser. ${ }^{39}$ 


\section{REVIEW ARTICLE}

\begin{tabular}{|c|c|c|c|c|}
\hline $\begin{array}{l}\text { Types of } \\
\text { injury }\end{array}$ & Clinical signs & Investigation & Treatment & Mechanisms of injury \\
\hline Eyelid injury ${ }^{42}$ & Lid retraction, lagophthalmos & Photography of external adnexa & Topical lubricant, punctal plug & \multirow{7}{*}{$\begin{array}{l}\text { Handheld laser devices: playing } \\
\text { with laser, }{ }^{21} \text { accidental injury } \\
\text { inflicted by other, }{ }^{21} \text { self-inflicted } \\
\text { injury, }{ }^{24} \text { intentional self-harm, } \\
\text { assault }{ }^{26} \\
\text { Medical laser devices: cosmetic } \\
\text { laser procedure, }{ }^{43} \text { laser removal } \\
\text { of skin lesion, }{ }^{32} \text { laser epilation of } \\
\text { eyelid }^{30} / \text { eyebrow, }{ }^{29,51} \text { ophthalmic } \\
\text { laser application }{ }^{4950} \\
\text { Occupational exposure to laserer } \\
\text { Air flight exposure to laser }{ }^{39} \\
\text { Recreational exposure to laser }{ }^{28} \\
\text { Military laser accident }{ }^{37,38}\end{array}$} \\
\hline $\begin{array}{l}\text { Corneal } \\
\text { injury }{ }^{33,63}\end{array}$ & $\begin{array}{l}\text { Bullous keratopathy, intrastromal } \\
\text { bleeding, corneal burn with scar, } \\
\text { corneal ulcer, corneal perforation, } \\
\text { exposure keratopathy }\end{array}$ & $\begin{array}{l}\text { Slit-lamp photography, corneal } \\
\text { sensation, tear break-up time, } \\
\text { basal secretion test }\end{array}$ & $\begin{array}{l}\text { Topical antibiotics, topical } \\
\text { prednisolone, ocular patching, } \\
\text { contact lens, corneal transplant }\end{array}$ & \\
\hline $\begin{array}{l}\text { Iris / uveal } \\
\text { tissue } \\
\text { injury } \\
32,35,51,87\end{array}$ & $\begin{array}{l}\text { Iris atrophy, corectopia, posterior } \\
\text { synechiae, atonic pupil, uveitis }\end{array}$ & Slit-lamp photography & $\begin{array}{l}\text { Topical and oral prednisolone, } \\
\text { cycloplegic eyedrop, pilocarpine } \\
\text { (for atonic pupil), subtenon } \\
\text { triamcinolone }\end{array}$ & \\
\hline $\begin{array}{l}\text { Lens } \\
\text { injury } \\
\end{array}$ & Cataract & Slit-lamp photography & Cataract surgery & \\
\hline $\begin{array}{l}\text { Elevated } \\
\text { intraocular } \\
\text { pressure }^{36}\end{array}$ & Corneal edema & Goldmann applanation tonometry & Pressure-lowering agents & \\
\hline $\begin{array}{l}\text { Visual field } \\
\text { defect }^{62}\end{array}$ & $\begin{array}{l}\text { Scotoma, peripheral visual field } \\
\text { loss }\end{array}$ & $\begin{array}{l}\text { Automated perimetry, } \\
\text { microperimetry }\end{array}$ & - & \\
\hline $\begin{array}{l}\text { Retinal } \\
\text { injury } 28,48,88\end{array}$ & $\begin{array}{l}\text { Hypo- or hyper-pigmentation, } \\
\text { yellow submacular lesion, } \\
\text { vitreous/preretinal/subretinal } \\
\text { hemorrhage, retinal pigment } \\
\text { epithelium changes, chorioretinal } \\
\text { scar, epiretinal membrane, full- } \\
\text { thickness macular hole, choroidal } \\
\text { neovascularization }\end{array}$ & $\begin{array}{l}\text { Fundus photography (color, } \\
\text { infrared or autofluorescence), } \\
\text { Amsler grid, fluorescein } \\
\text { angiography, optical coherence } \\
\text { tomography, optical coherence } \\
\text { tomography angiography, } \\
\text { electroretinography }\end{array}$ & $\begin{array}{l}\text { Topical or oral prednisolone, } \\
\text { intravenous methylprednisolone, } \\
\text { anti-vascular endothelial } \\
\text { growth factors, Nd:YAG laser } \\
\text { hyaloidotomy, pars plana } \\
\text { vitrectomy }+/ \text { - internal limiting } \\
\text { membrane peeling }+/ \text { - intraocular } \\
\text { gas tamponade }\end{array}$ & \\
\hline
\end{tabular}

Laser is commonly used in aesthetic and dermatological medicine, including treatment of pigmented or vascular lesions, hair removal, and facial rejuvenation..$^{40,41}$ The eyelid skin is thin and lacks subcutaneous fat, leaving the globe vulnerable to both anterior or posterior segment injury from laser energy absorption. ${ }^{35,41}$ Laser skin resurfacing has been reported to cause thermal injury of the eyelid and corneal damage. ${ }^{42,43}$ Anterior segment injury from laser-assisted eyebrow epilation is commonly reported..$^{44,45}$

Occupational laser-induced injuries are primarily associated with pulsed lasers such as Nd:YAG laser in industrial or laboratory settings. ${ }^{1}$ Recreational exposure to laser in laser light show has been reported to cause retinal injury, ${ }^{28,46}$ as has accidental laser exposure in military exercises, actual combat, ${ }^{38}$ and civilian airflight. ${ }^{1,5}$

Patients can usually recall a history of exposure to laser devices. However, elusive exposure history and delayed clinical presentation are not uncommon among pediatric patients. ${ }^{4,22}$ Sudden onset of unilaterally decreased vision is the typical presentation of visually significant retinal laser injury. ${ }^{47}$ The severity of visual loss depends on the proximity of the laser impact site to the fovea, the extent of chorioretinal disruption, and the amount of intraocular bleeding., ${ }^{4,21,47,48}$ Apart from the posterior segment, laser may cause injury of the external adnexa and the anterior segment (Table 2). Common symptoms include eye pain, temporary loss of vision, and conjunctival erythema. ${ }^{41}$ Mechanisms of injury involving external adnexa and anterior segments tend to differ from those of retinal injury and are often associated with dermatological laser procedure ${ }^{43}$ and ophthalmic laser application. ${ }^{49,50}$ Anterior segment injuries are more commonly induced by lasers of longer wavelength such as Alexandrite laser $(755 \mathrm{~nm})$ and diode laser $(810 \mathrm{~nm})$ used in epilation of eyebrow ${ }^{30-36}$ and carbon dioxide laser used in skin resurfacing. ${ }^{42,43}$ Alexandrite laser and diode laser are readily absorbed by the heavily pigmented iris, causing iris atrophy and corectopia. ${ }^{30-32,34-36,51}$ They can result in normotensive or hypertensive anterior uveitis, leading to posterior synechiae formation. ${ }^{31-36}$ Carbon dioxide laser may lead to exposure keratopathy secondary to lower lid retraction. ${ }^{42}$ Cataract formation $^{30,51}$ and cataract in infants treated with argon laser photocoagulation for threshold retinopathy of prematurity have been reported. ${ }^{52}$ Although the extent of corneal injury associated with laser procedures is often mild ${ }^{53}$ severe corneal damage with bullous keratopathy or corneal perforation ${ }^{54}$ necessitating penetrating keratoplasty ${ }^{43}$ has been reported.

In a systematic review on retinal injury secondary to laser pointer exposure, $55 \%$ of patients have visual acuity of less than 20/40 at presentation, around $9 \%$ of patients have $20 / 20$ or better, and $5 \%$ of patient had visual acuity of finger counting. The most common fundoscopic finding was pigmentary changes with hypo- or hyperpigmentation (53\%), followed by yellow foveal lesions (33\%), macular hole (23\%), and hemorrhage (14\%). Although a large proportion of laserinduced ocular injury improves spontaneously, medical and/ or surgical intervention may be required for complications such as subretinal, intraretinal, subhyaloid, and preretinal 
hemorrhage, full-thickness macular hole, and epiretinal membrane and choroidal neovascularization. . $^{7,21,22,28,48,55-57}$ One case report described rod and cone cells dysfunction leading to diffuse peripheral visual field defect following a diode laser injury. ${ }^{34}$

Differential diagnoses of laser-induced retinal injury include retinal dystrophies (eg, Best disease and Stargardt disease) and inflammatory and ischemic retinopathies. ${ }^{4,7}$ Laser-induced injuries rarely progress following acute damage, but inherited retinal diseases are characterized by bilateral involvement and gradual progression. Multimodal investigations including sequential OCT and electrophysiology tests are occasionally indicated. ${ }^{4,58}$ Some cases of laser-induced retinal injury in pediatric patients have been mistakenly referred to the genetic service for possible inherited retinal disease. ${ }^{58}$ Behavioral or psychiatric conditions have been reported to be associated with self-inflicted laser insults. ${ }^{23,59}$ Attention deficit hyperactivity disorder and autism spectrum disorders are proposed to increase the risk of such injuries. ${ }^{23}$ Psychiatric conditions should be recognized and collaboration with mental health experts may be necessary. ${ }^{23}$

\section{Investigation}

Laser-induced ocular injury may have considerable legal, financial, and medical consequences. ${ }^{60}$ Accurate diagnosis requires detailed history taking and prompt ophthalmic assessment, as clinical signs are often transient and subtle. ${ }^{61}$ If the mechanism of laser exposure and clinical examination findings are ambiguous, further investigations may be used to confirm ocular insult secondary to the alleged accident. Documentation of best-corrected visual acuity is essential. Photographic documentation of external adnexa, anterior segment, or fundus is invaluable to record clinically apparent pathologies following laser-induced injury. Slit-lamp examination, Goldmann applanation tonometry, corneal sensation, tear break-up time, and basal secretion test can be performed if the anterior segment is involved. Infrared photography and fundus autofluorescence may help to characterize the retinal lesion. ${ }^{61}$ Amsler grid testing shows subjective functional deficits including metamorphopsia and scotoma.

Fluorescein angiography of acute photocoagulation laserinduced injuries typically produces a hyperfluorescent ring with a hypofluorescent center. ${ }^{60}$ In cases with secondary vitreous or chorioretinal hemorrhages, a hypofluorescent area secondary to overlying blockage may be observed. ${ }^{28}$ As the hemorrhage resolves and RPE atrophy ensues, a hyperfluorescent window defect may develop. Late retinal fibrosis or chorioretinal scarring give rise to hyperfluorescence owing to staining. Choroidal neovascularization can also be demonstrated with active leakage. ${ }^{48}$ Incidental findings of minor angiographic abnormalities are not uncommon in normal individuals and should be interpreted with caution before attributing it to a laser-induced injury. ${ }^{62}$

OCT of the macula may demonstrate a spectrum of features including RPE change, focal inner segment-outer segment junction disruption, retinal edema and cystoid changes, hemorrhages, and macular hole. ${ }^{4}$ The outer retina often demonstrates localized hyperreflectivity, accompanied by persistent disruption of the outer retinal layers. ${ }^{7}$ OCT angiography is useful to detect choroidal ischemia or choroidal neovascularization. ${ }^{48}$ Based on OCT features, a classification of laser-induced retinal injuries has been proposed to quantify retinal laser energy absorption and RPE damage. ${ }^{22}$ However, it is difficult to correlate the severity of injury based on OCT features with the degree of visual impairment or prognosis., ${ }^{422}$ Electroretinography can be used to assess possible rod and cone cells dysfunction following laser-induced injury. ${ }^{34}$

Functionally, automated perimetry and microperimetry may be used to document visual field defects or reduced macular sensitivity. ${ }^{7}$ Follow-up examinations may be arranged to monitor visual field deficits, which may spontaneously improve or remain static. ${ }^{61}$

\section{Treatment}

There is no evidence-based consensus on treatment for laser-induced ocular injury. In general, visual symptoms and anatomical changes tend to improve with time, although permanent vision loss and scotoma may persist in some patients. ${ }^{4}$ Watchful waiting may be a reasonable option for relatively mild cases, especially for injuries of the extrafoveal or peripheral retina..$^{4,7}$

Treatment is largely determined by the extent of injury and includes medical and/or surgical management. Superficial lesions to the corneal epithelium can be treated with topical antibiotics, patching, or contact lenses. ${ }^{63}$ Lid retraction and lagophthalmos are managed with topical lubricants or punctal plug. ${ }^{42}$ Cycloplegic eyedrops, topical or oral steroids at varying treatment lengths are helpful to reduce the damaging inflammatory response to injury. ${ }^{35}$ Subtenon triamcinolone has been used to manage severe anterior uveitis. ${ }^{35}$ Pressurelowering agents can be used for increased intraocular pressure, and pilocarpine can be used to manage pupil distortion after laser-induced injury. ${ }^{51}$

Topical or systemic corticosteroids have been used to treat laser-induced retinopathy in the belief that they reduce production of inflammatory cytokines, limit neutrophil infiltration, and reduce retinal photoreceptor damage and glial scar formation., ${ }^{1,47,64-66}$ Systemic methylprednisolone and indomethacin in animal study improve photoreceptor survival after laser-induced injury.,48,67,68 However, negative effects of methylprednisolone in animal model with laserinduced retinal injury have also been reported.$^{69}$ The clinical efficacy of corticosteroids in humans is based on case reports only. 1,11,22,28,70-72 The therapeutic effect of medications is often confounded by the natural course of ocular injury. 22,27,73,74 Overall, the role of systemic corticosteroid and non-steroidal anti-inflammatory agents in laser-induced retinopathy remains inconclusive.

Various medications including oral lutein, deferoxamine, and human recombinant fibroblast growth factors have been 
used in the treatment of laser-induced retinal injury., ${ }^{4,75,76}$ However, results vary widely and are largely experimental. Anti-vascular endothelial growth factors may be of value if secondary choroidal neovascularization develops. ${ }^{48}$ There is limited evidence on the indication, dosage, and therapeutic window of medical therapy for laser-induced retinopathy, and the usage of various medical therapies remains controversial.

Severe corneal injury leading to bullous keratopathy or corneal opacity with vision loss may require surgical intervention such as corneal transplantation. ${ }^{43,63}$ Mild cataracts can be managed conservatively, whereas surgery is considered for visually significant cataracts. ${ }^{51,52}$ Surgical intervention may be considered if there is significant intraocular hemorrhage. It is particularly beneficial in cases that require prompt restoration of vision. ${ }^{1}$ As pre-retinal blood may induce fibrosis with formation of chorioretinal scar, epiretinal membrane or secondary macular hole, ${ }^{21,77}$ pars plana vitrectomy may be used for vitreous or pre-retinal hemorrhage that do not clear spontaneously within a short period. ${ }^{57} \mathrm{Nd}$ :YAG laser hyaloidotomy may be an option for cases of subhyaloid or sub-internal limiting membrane hemorrhages., ${ }^{21,78,79}$ Laserinduced macular hole can occur immediately or several days after injury. ${ }^{21,80,81}$ Spontaneous closure of macular hole has been reported for smaller macular holes $(<250 \mu \mathrm{m}),{ }^{82}$ and observation can be considered..$^{83,84}$ Macular holes of $>250 \mu \mathrm{m}$ are indicated for surgical intervention to prevent further anatomical and functional deterioration. ${ }^{84,85}$ Pars plana vitrectomy with internal limiting membrane peeling and intraocular gas tamponade is used to treat eyes with fullthickness macular hole secondary to laser injury. ${ }^{21,84,85}$

\section{Prognosis}

The prognosis for laser-induced retinal injuries is generally favorable. Laser-induced injury involving external adnexa and anterior segment generally have good outcome with visual acuity of $20 / 40$ or better. ${ }^{32}$ In a review of laser-induced retinal injury, $55 \%$ of eyes recovered to visual acuity of 20/25 or better within a few months and $36 \%$ recovered to visual acuity of 20/100 to 20/30. ${ }^{1}$ Nevertheless, a large proportion of patients have visual acuity worse than $20 / 200$, especially those in younger age-groups. ${ }^{4,23}$ In general, the further away the lesion is from the fovea, the better the recovery. However, development of late complications may adversely affect the outcome. Chorioretinal scarring is the most common complication. ${ }^{4,48}$ Other sequelae including macular hole, macular cyst, epiretinal membrane formation, and choroidal neovascularization can lead to unfavorable visual outcome. , $^{4,48,84}$

\section{Preventive measures}

In Hong Kong, there is no statutory regulation on the purchase or usage of laser-incorporated products even for high-energy output classes 3 or 4 lasers. ${ }^{62}$ Hand-held laser pointers are commonly used for educational and recreational purposes, giving rise to an increasing incidence of laser-induced ocular injury. ${ }^{28,56}$ Public education on the potential harmful effects of lasers should be reinforced in order to prevent accidental or deliberate laser injuries. ${ }^{2}$ Furthermore, manufacturers and sellers of laser devices should affix proper explanatory and warning labels to laser products. ${ }^{86}$

In the occupational setting, it is important to ensure that the environment is optimal for the safe operation of laser machines, and all staff are compliant to laser safety protocols. Covering all reflective surfaces and ensuring the room door is locked while a laser is in use are simple but effective measures to minimize inadvertent injuries. Because lasers are monochromatic in nature, wavelength-specific filters are effective in blocking specific laser beams while allowing sufficient light of other wavelengths to be transmitted. ${ }^{1}$ These filters are used in safety goggles and operative microscopes to protect operators from laser exposure. Safety goggles with correct corresponding wavelength should be used when operating or switching between laser machines. For patients receiving therapeutic laser treatments, protective eye wear should be used when appropriate..$^{87,88}$

\section{Conclusion}

Laser-induced ocular injury may cause permanent visual sequelae and functional disability. Making an accurate diagnosis may have potential medicolegal consequences, and thus it should be supported by clinical findings and/or appropriate investigations. Timely assessment is important, as clinical signs may be temporary and subtle. Prevention and protection of laser-induced ocular injuries is more important than treatment. Awareness of the potential hazardous effects of laser use should be reinforced among healthcare providers and the general public.

\section{Author contributions}

Concept or design: EW, FL

Acquisition of data: EW, AL

Analysis or interpretation of data: EW, AL, FL

Drafting of the article: EW, AL, FL

Critical revision for important intellectual content: RL, FL

All authors had full access to the data, contributed to the study, approved the final version for publication, and take responsibility for its accuracy and integrity.

\section{Conflicts of interest}

All authors have no conflicts of interest to disclose.

\section{Funding/Support}

This research received no specific grant from any funding agency in the public, commercial, or not-for-profit sectors.

\section{Ethics approval}

The patient was treated in accordance with the Declaration of Helsinki. The patient provided written informed consent for treatments and procedures. 


\section{References}

1. Barkana Y, Belkin M. Laser eye injuries. Surv Ophthalmol 2000;44:459-78. crossret

2. Torp-Pedersen T, Welinder L, Justesen B, et al. Laser pointer maculopathy - on the rise? Acta Ophthalmol 2018;96:74954. crossref

3. Altwijri R, Alsuliman SA, Alanazi L, et al. Knowledge and attitude towards hazardous effects of laser pointers among attendees of football matches in Riyadh, Saudi Arabia. Saudi J Ophthalmol 2020. crossref

4. Neffendorf JE, Hildebrand GD, Downes SM. Handheld laser devices and laser-induced retinopathy (LIR) in children: an overview of the literature. Eye (Lond) 2019;33:120314. crossref

5. Nakagawara VB, Montgomery RW. Laser pointers and aviation safety. Aviat Space Environ Med 2000;71:1060-2.

6. Alsulaiman SM, Al-Qahtani A, Mousa A, Ghazi NG. Laser pointers: how much does the general medical community know? Graefes Arch Clin Exp Ophthalmol 2017;255:6356. Crossref

7. Birtel J, Harmening WM, Krohne TU, et al. Retinal injury following laser pointer exposure. Dtsch Arztebl Int 2017;114:831-7. Crossref

8. American National Standards Institute. American National Standard for Safe Use of Lasers, ANSI Z136.1.2007.

9. BSEN 60825: 992. Radiation safety of laser products, equipment, classification, requirements and users guide. British Standards Institution; 1992.

10. Hadler J, Tobares EL, Dowell M. Random testing reveals excessive power in commercial laser pointers. J Laser Appl 2013;10:2351/1.4798455.

11. Xu K, Chin EK, Quiram PA, Davies JB, Parke DW 3rd, Almeida DR. Retinal injury secondary to laser pointers in pediatric patients. Pediatrics 2016;138:e20161188. Crossref

12. Retail shops fined for supplying unsafe laser pointers. Customs and Excise Department https://www.customs.gov.hk/en/ publication_press/press/index_id_1583.html. Accessed 15 May 2020.

13. Safety of Laser Products - Part 1: Equipment Classification and Requirements. 2nd ed. International Electrotechnical Commission; 2007.

14. Mainster MA, Sliney DH, Belcher CD 3rd, Buzney SM. Laser photodisruptors. Damage mechanisms, instrument design and safety. Ophthalmology 1983;90:973-91. Crossref

15. Marshall J. Thermal and mechanical mechanisms in laser damage to the retina. Invest Ophthalmol 1970;9:97-115.

16. Ham WT Jr, Ruffolo JJ Jr, Mueller HA, Guerry D 3rd. The nature of retinal radiation damage: dependence on wavelength, power level and exposure time. Vision Res 1980;20:1105-11. Crossref

17. Boettner EA, Wolter JR. Transmission of the ocular media. Invest Ophthalmol Vis Sci 1962;1:776-83.

18. Whitmer DL, Stuck BE.Directed energy (laser) induced retinal injury: current status of safety, triage, and treatment research . US Army Med Dep J 2009:51-6.

19. Krauss JM, Puliafito CA, Steinert RF. Laser interactions with the cornea. Surv Ophthalmol 1986;31:37-53. Crossref

20. Peppers NA, Vassiliadis A, Dedrick KG, et al.Corneal damage thresholds for CO2 laser radiation. Appl Opt 1969;8:37781. crossref

21. Alsulaiman SM,Alrushood AA, Almasaud J, et al.High-power handheld blue laser-induced maculopathy: the results of the King Khaled Eye Specialist Hospital Collaborative Retina Study Group. Ophthalmology 2014;121:566-72.e1. Crossref
22. Raoof N, Bradley P, Theodorou M, Moore AT, Michaelides M. The new pretender: a large UK case series of retinal injuries in children secondary to handheld lasers. Am J Ophthalmol 2016;171:88-94. Crossret

23. Linton E, Walkden A, Steeples LR, et al. Retinal burns from laser pointers: a risk in children with behavioural problems. Eye (Lond) 2019;33:492-504. crossref

24. Dirani A, Chelala E, Fadlallah A, Antonios R, Cherfan $G$. Bilateral macular injury from a green laser pointer. Clin Ophthalmol 2013;7:2127-30. Crossref

25. Bhavsar KV, Wilson D, Margolis R, et al. Multimodal imaging in handheld laser-induced maculopathy. Am J Ophthalmol 2015;159:227-31.e2. Crossref

26. Sethi CS, Grey RH, Hart CD. Laser pointers revisited: a survey of 14 patients attending casualty at the Bristol Eye Hospital. Br J Ophthalmol 1999;83:1164-7. crossref

27. Scollo P, Herath $G$, Lobo A. Retinal injury by industrial laser burn. Occup Med (Lond) 2014;64:220-2. Crossref

28. Aras C, Koyluoglu N, Hasheminia A, Akaydin O. Inadvertent laser-induced retinal injury following a recreational laser show. Clin Exp Ophthalmol 2009;37:529-30. crossref

29. Asiri MS, Alharbi M, Alkadi T, et al.Ocular injuries secondary to alexandrite laser-assisted hair removal. Can J Ophthalmol 2017;52:e71-e75. Crossref

30. Brilakis HS, Holland EJ. Diode-laser-induced cataract and iris atrophy as a complication of eyelid hair removal. Am J Ophthalmol 2004;137:762-3. Crossref

31. Halkiadakis I, Skouriotis S, Stefanaki C, et al. Iris atrophy and posterior synechiae as a complication of eyebrow laser epilation.J Am Acad Dermatol 2007;57(2 Suppl):S4-5. Crossref

32. Crowell EL, Jampel H, Berkenstock M. Alexandrite laser induced uveitis \& pigment dispersion: a case report and review of the literature. Am J Ophthalmol Case Rep 2020;18:100632. Crossref

33. Yalcindag FN, Uzun A. Anterior uveitis associated with laser epilation of eyebrows. J Ophthalmic Inflamm Infect 2013;3:45. Crossref

34. Sheikh A, Hodge W, Coupland S. Diode laser-induced uveitis and visual field defect. Ophthalmic Plast Reconstr Surg 2007;23:321-3. Crossref

35. Lin CC, Tseng PC, Chen CC, Woung LC, Liou SW. Iritis and pupillary distortion after periorbital cosmetic alexandrite laser. Graefes Arch Clin Exp Ophthalmol 2011;249:7835. crossref

36. Gulmez Sevim D, Oner AO, Unlu M, Mirza GE. Ocular complications after cosmetic periocular diode laser application to the eyelids.J Cosmet Laser Ther 2018;20:4478. Crossref

37. Alhalel A, Glovinsky Y, Treister G, Bartov E, Blumenthal M, Belkin M. Long-term follow up of accidental parafoveal laser burns. Retina 1993;13:152-4. Crossref

38. Mader TH, Aragones JV, Chandler AC, et al. Ocular and ocular adnexal injuries treated by United States military ophthalmologists during Operations Desert Shield and Desert Storm. Ophthalmology 1993;100:1462-7. Crossref

39. Gosling DB, O'Hagan JB, Quhill FM. Blue laser induced retinal injury in a commercial pilot at $1300 \mathrm{ft}$. Aerosp Med Hum Perform 2016;87:69-70. crossref

40. Yan MK, Kocak E, Yoong K, Kam JK. Ocular injuries resulting from commercial cosmetic procedures. Clin Exp Optom 2020;103:430-3. crossre

41. Huang A, Phillips A, Adar T, Hui A. Ocular injury in cosmetic laser treatments of the face.J Clin Aesthet Dermatol 2018;11:15-8.

42. Miedziak AI, Gottsch JD, Iliff NT. Exposure keratopathy after 
cosmetic CO2 laser skin resurfacing. Cornea 2000;19:8468. Crossref

43. Widder RA, Severin M, Kirchhof B, Krieglstein GK. Corneal injury after carbon dioxide laser skin resurfacing. Am J Ophthalmol 1998;125:392-4. Crossref

44. Karabela Y, Eliacik M. Anterior uveitis following eyebrow epilation with alexandrite laser. Int Med Case Rep J 2015;8:177-9. Crossref

45. Parver DL, Dreher RJ, Kohanim S, et al. Ocular injury after laser hair reduction treatment to the eyebrow. Arch Ophthalmol 2012;130:1330-4. Crossref

46. Shneck M, Levy J, Klemperer I, Lifshitz T. Retinal laser injury during a laser show. Retin Cases Brief Rep 2007;1:17881. Crossref

47. Lee GD, Baumal CR, Lally D, Pitcher JD, Vander J, Duker $J S$. Retinal injury after inadvertent handheld laser exposure. Retina 2014;34:2388-96. Crossref

48. Tran K, Wang D, Scharf J, Sadda S, Sarraf D. Inner choroidal ischaemia and $C N V$ due to handheld laserinduced maculopathy: a case report and review. Eye (Lond) 2020. crossref

49. McCanna R, Chandra SR, Stevens TS, Myers FL, de Venecia G, Bresnick GH.Argon laser-induced cataract as a complication of retinal photocoagulation. Arch Ophthalmol 1982;100:10713. Crossref

50. Lakhanpal V, Schocket SS, Richards RD, Nirankari VS. Photocoagulation-induced lens opacity. Arch Ophthalmol 1982;100:1068-70. Crossref

51. Herbold TM, Busse H, Uhlig CE. Bilateral cataract and corectopia after laser eyebrow [corrected] epilation. Ophthalmology 2005;112:1634-5. Crossref

52. Christiansen SP, Bradford JD. Cataract in infants treated with argon laser photocoagulation for threshold retinopathy of prematurity. Am J Ophthalmol 1995;119:175-80. crossref

53. Irvine WD, Smiddy WE, Nicholson DH.Corneal and iris burns with the laser indirect ophthalmoscope. Am J Ophthalmol 1990;110:311-3. crossref

54. Keithahn MA, Gross RH, Mannis MJ, Morales RB, Morse LS. Corneal perforation associated with argon laser photocoagulation for a retinal tear. Am J Ophthalmol 1997;123:125-7. Crossref

55. Yeo DC, Osei-Bempong C, Shirodkar A, Williams GS. Foveal haemorrhage from makeshift 'Lightsaber': funduscopy and optical coherence tomography findings. BMJ Case Rep 2016;2016: bcr2016214711. Crossref

56. Үiu G, Itty $S$, Toth $C A$. Ocular safety of recreational lasers. JAMA Ophthalmol 2014;132:245-6. Crossref

57. Perez-Montano CR, Palomares-Ordonez JL, RamirezEstudillo A, Sanchez-Ramos J, González-Saldivar G. Sub-hyaloid and sub-internal limiting membrane macular hemorrhage after laser exposure at music festival: a case report. Doc Ophthalmol 2019;138:71-6. Crossref

58. Zhang L, Zheng A, Nie H, et al. Laser-induced photic injury phenocopies macular dystrophy. Ophthalmic Genet 2016;37:59-67. Crossref

59. Dolz-Marco R, Cunha Souza E, Iida T, et al. Iris atrophy: a novel sign of repeated self-inflicted laser pointer maculopathy. Retina 2017;37:e26-e28. Crossref

60. Mainster MA, Stuck BE, Brown J Jr. Assessment of alleged retinal laser injuries. Arch Ophthalmol 2004;122:12107. Crossref

61. Dhrami-Gavazi E, Lee W, Balaratnasingam C, Kayserman L, Yannuzzi LA, Freund KB. Multimodal imaging documentation of rapid evolution of retinal changes in handheld laser-induced maculopathy. Int J Retina Vitreous 2015;1:14. Crossref
62. Shum JW, Iu LP, Cheung DN, Wong IY. A case of accidental ocular injury from cosmetic laser burn. Retin Cases Brief Rep 2016;10:115-20. Crossref

63. Thach AB. Laser injuries of the eye. Int Ophthalmol Clin 1999;39:13-27. Crossref

64. Hacker HD, Brown J Jr, Cheramie R, Stuck BE. New approaches to the diagnosis and management of laser eye injury. Proceeding of SPIE 6426, Ophthalmic Technologies XVII, 642623.5 March 2007. crossref

65. Hossein M, Bonyadi J, Soheilian R, Soheilian M, Peyman GA. SD-OCT features of laser pointer maculopathy before and after systemic corticosteroid therapy. Ophthalmic Surg Lasers Imaging 2011;42:e135-e138. Crossref

66. Lim ME, Suelzer J, Moorthy RS, Vemuri G. Thermal macular injury from a $154 \mathrm{~mW}$ green laser pointer. J AAPOS 2014;18:612-4. crossref

67. Takahashi K, Lam TT, Fu J, Tso MO. The effect of highdose methylprednisolone on laser-induced retinal injury in primates: an electron microscopic study. Graefes Arch Clin Exp Ophthalmol 1997;235:723-32. Crossref

68. Brown J Jr, Hacker H, Schuschereba ST, Zwick H, Lund DJ, Stuck BE. Steroidal and nonsteroidal antiinflammatory medications can improve photoreceptor survival after laser retinal photocoagulation. Ophthalmology 2007;114:187683. Crossref

69. Solberg Y, Dubinski G, Tchirkov M, Belkin M, Rosner M. Methylprednisolone therapy for retinal laser injury. Surv Ophthalmol 1999;44 Suppl 1:S85-92. Crossref

70. Mtanes K, Mimouni M,Zayit-Soudry S.Laser pointer-induced maculopathy: more than meets the eye.J Pediatr Ophthalmol Strabismus 2018;55:312-8. crossref

71. Chen X, Dajani OAW, Alibhai AY, Duker JS, Baumal CR. Long-term visual recovery in bilateral handheld laser pointer-induced maculopathy. Retin Cases Brief Rep 2019;10.1097. Crossref

72. Robertson DM, McLaren JW, Salomao DR, Link TP. Retinopathy from a green laser pointer: a clinicopathologic study. Arch Ophthalmol 2005;123:629-33. crossref

73. Weng CY, Baumal CR, Albini TA, Berrocal AM. Self-induced laser maculopathy in an adolescent boy utilizing a mirror. Ophthalmic Surg Lasers Imaging Retina 2015;46:4858. Crossret

74. Turaka K, Bryan JS, Gordon AJ, Reddy R, Kwong HM Jr, Sell $C H$. Laser pointer induced macular damage: case report and mini review. Int Ophthalmol 2012;32:293-7. crossref

75. Schuschereba ST, Bowman PD, Ferrando RE, Lund DJ, Quong $J A$, Vargas JA. Accelerated healing of laser-injured rabbit retina by basic fibroblast growth factor. Invest Ophthalmol Vis Sci 1994;35:945-54.

76. Zhao N, Liu L. Long-term changes in optic coherence tomography in a child with laser pointer maculopathy: a case report and mini review. Photodiagnosis Photodyn Ther 2017;18:264-6. crossref

77. Bernstein PS, Steffensmeier A. Optical coherence tomography before and after repair of a macular hole induced by an unintentional argon laser burn. Arch Ophthalmol 2005;123:404-5. Crossre

78. Heichel J, Kuehn E, Eichhorst A, Hammer T, Winter I.Nd:YAG laser hyaloidotomy for the treatment of acute subhyaloid hemorrhage: a comparison of two cases. Ophthalmol Ther 2016:5:111-20. crossref

79. Gabel VP, Birngruber R, Gunther-Koszka H, Puliafito CA. $N d: Y A G$ laser photodisruption of hemorrhagic detachment of the internal limiting membrane. Am J Ophthalmol 1989;107:33-7. Crossref 
80. Dhoot DS, Хu D, Srivastava S. High-powered laser pointer injury resulting in macular hole formation. $J$ Pediatr 2014;164:668.e1. Crossref

81. Petrou P, Patwary S, Banerjee PJ, Kirkby GR. Bilateral macular hole from a handheld laser pointer. Lancet 2014;383:1780. Crossref

82. Thach AB, Lopez PF, Snady-McCoy LC, Golub BM, Frambach $D A$. Accidental Nd:YAG laser injuries to the macula. Am J Ophthalmol 1995;119:767-73. Crossref

83. Alsakran WA, Alsulaiman SM, Ghazi NG.Delayed spontaneous closure of blue laser-induced full thickness macular hole. Am J Ophthalmol Case Rep 2019;13:154-6. crossref

84. Alsulaiman SM, Alrushood AA, Almasaud J, et al. Fullthickness macular hole secondary to high-power handheld blue laser: natural history and management outcomes. Am J Ophthalmol 2015;160:107-13.e1. Crossret
85. Qi Y, Wang Y, You Q, Tsai F, Liu W. Surgical treatment and optical coherence tomographic evaluation for accidental laser-induced full-thickness macular holes. Eye (Lond) 2017;31:1078-84. crossref

86. Safety Guidelines for Laser Products. Electrical and Mechanical Services Department https://www.emsd.gov. hk/en/other_regulatory_services/laser_safety/publications/ safety_guidelines_for_laser_products/index.html. Accessed 15 May 2020.

87. Hammes $S$, Augustin A, Raulin C, Ockenfels HM, Fischer E. Pupil damage after periorbital laser treatment of a port-wine stain. Arch Dermatol 2007;143:392-4. Crossref

88. Bulut MN, Calli U, Goktas E, Bulut K, Kandemir B, Özertïrk $Y$. Use of an intravitreal dexamethasone implant (Ozurdex) in a case with accidental foveal photocoagulation by alexandrite laser. Case Rep Ophthalmol 2016;7:130-4. Crossref 